\title{
MIR19B1 Gene
}

National Cancer Institute

\section{Source}

National Cancer Institute. MIR19B1 Gene. NCI Thesaurus. Code C80737.

This gene is involved in the regulation of gene expression and plays a role in the development of hepatocellular carcinoma, plasma cell myeloma and medulloblastoma. 